\title{
Eğitim Sektöründe Hizmet Kalitesinin Ölçülmesi: Öğrenci İşleri Birimi Örneği ${ }^{1}$
}

\author{
Nurettin Ayaz ${ }^{a^{*}}$, Ahmet Arakaya $^{\mathrm{b}}$ \\ ${ }^{a}$ Karabük Üniversitesi, Safranbolu Turizm Fakültesi, Karabük. \\ ${ }^{b}$ Karabük Üniversitesi, Sosyal Bilimler Enstitüsü Iş̧letme Anabilim Dalı, Karabük.
}

\begin{abstract}
Öz
Hizmet sunumu yapan işletmelerde somut ürünler yerine soyut ürünlerin öne çıkması nedeniyle müşterilerin kalite beklentilerini ölçümlemek daha zordur. Bununla birlikte hizmet kalitesinin ölçümü bağlamında SERVQUAL ölçeği kullanılması önerilmektedir. Bu araştırmada yüksek öğretim kurumları tarafindan sunulan hizmetlerden bir tanesi olan öğrenci işleri birimi hizmetleri, öğrenciler perspektifinden değerlendirilmektedir. Bu kapsamda 2014-2015 öğretim yılı içerisinde 507 üniversite öğrencisinden basit tesadüfi örnekleme yöntemi kapsamında anket tekniğ $i$ kullanılarak veri toplanmıştır. Verilerin analizi sonucunda öğrenci işleri birimi tarafından sunulan hizmetler için güvenilirlik, heveslilik, fiziksel özellikler, empati ve güven olmak üzere beş boyuta ulaşılmıştır. Bu boyutlar çerçevesinde Karabük Üniversitesi öğrenci işleri biriminin algilanan ve beklenen hizmet kalitesi karşılaştırılmış, SERVQUAL skoru -0,49 olarak hesaplanmıştır. Bu sonuç göstermektedir ki öğrenci işleri birimi hizmet kalitesi konusunda iyi bir konumdadır. Bununla birlikte hizmet kalitesini geliştirme yönünde küçük düzenlemelere ihtiyacı bulunmaktadır.
\end{abstract}

Anahtar Kelimeler: Hizmet, hizmet kalitesi, SERVQUAL, öğrenci işleri birimi.

\section{Measurement of Service Quality in Education Sector: The Example of Student Affairs Unit}

\begin{abstract}
It is quite difficult to measure the quality expectations of the clientele due to the fact that concrete products come into prominence rather than abstract ones in the businesses offering service to the society. However, the scale of SERVQUAL is recommended with regard to measuring the service quality. This research assesses the services of student affairs unit which is one of the services presented by high educational institutions through the student perspective. Within this context, all relevant data are collected from 507 university students by means of a plain and random sample survey method in the academical year of 2014-2015. After an analysis of the data, the research has reached to five dimensions concerning the services offered by student affairs unit which include reliability, enthusiasm, empathy, trust and physical features. As part of these dimensions the service quality perceived and expected from the Student Affairs Unit of Karabük University is compared and its SERVQUAL score is calculated as -0,49. This result indicates that the said student affairs unit enjoys a good position regarding the service quality. Nevertheless it is still in need of little arrangements in order to enhance the service quality.
\end{abstract}

Keywords: Service, the service quality, SERVQUAL, student affairs.

\footnotetext{
${ }^{1}$ Bu araştırma, "Yükseköğretimde Hizmet Kalitesi Ölçümü: Öğrenci İşleri Daire Başkanlı̆̆ı Örneği" başlıklı tez çalışmasından oluşturulmuştur.
} 


\section{GİRIŞ}

Bireylerin ekonomik ürünleri ve hizmetleri satın alma ve kullanma kararı ile ilişkilendirilen tüketici davranışı (Odabaşı ve Barış, 2002) kapsamında işletmelerin müşteri beklentileriyle orantılı ve kaliteli hizmet sunabilmesi için hizmet kalitesini etkileyen faktörlerin, hizmeti alan kişi veya kuruluşların hizmet kalitesi beklentilerinin incelenmesi gerekmektedir. Bu durum, bir mal veya hizmete yönelik hedef pazarı detaylı bir şekilde analiz edebilme ve pazarlama karması (ürün, pazar, fiyat, tutundurma) elemanları etrafında bir pazarlama planı oluşturulması adına önemli bir gerekliliktir. Ayrıca hizmetlerin mallara göre daha geniş bir yelpaze içinde değişkenlik göstermesi, onların daha farklı düşünülmesi ve ele alınması gerekliliğini ortaya çıkarır (Üner, 1994).

Gelişmişliğin bir göstergesi olarak kabul edilen hizmet sektörü, gelişmiş ve gelişmekte olan ülkelerin ekonomilerinde geniş bir paya sahiptir. Tarihsel gelişim sürecinde tarım, küçük el sanatları ve buradan kitle üretimine geçişi öngören sanayinin ardından hizmetler, mal ve hizmet değişiminde bulunması ile öne çıkar hale gelmiştir (Altan ve Atan, 2004: 25). Türkiye' de de hizmet sektörünün ekonomi içindeki ağırlı̆̆1 ve önemi her geçen gün artmaktadır. 2015 istatistiklerine göre ana faaliyetlerden hizmetler sektörünün büyümeye katkısı \%2,3 olurken, inşaatı da kapsayan sanayi sektörünün katkısı \%1,2 oranında kalmıştır. Tarım sektöründe ise negatif yönlü olmak üzere $\% 0,2^{\prime}$ lik bir oran ortaya çıkmıştır (http://www.tuik.gov.tr).

Bu araştırma, dinamik bir süreçte kendisini sürekli bir şekilde yenileyen ve geliştiren hizmet sektörüne eğitim boyutunda katkı sağlamak düşüncesiyle hazırlanmıştır. Eğitim sektörü hizmetleri kapsamında Karabük Üniversitesi Öğrenci İşleri Daire Başkanlığı'ndan hizmet alan üniversite öğrencilerinin sunulan hizmetlere yönelik alg1 ve beklentileri SERVQUAL yöntemi ile ölçümlenmiş ve yüksek öğretim kurumları kapsamında sunulan hizmetlere öğrenciler perspektifinden öneriler geliştirmek amacıyla tasarlanmıştır.

\section{Yükseköğretim Kurumlarında Hizmet Kalitesi}

Bir toplumun varlığını sürdürmesi ve gelişmesinde eğitim sisteminde üretici bir alt sistem olan eğitim kurumlarının rol üstlenmeleri gerekir. Toplumun üyesi olan bireyin yeteneklerinin geliştirilmesinde ve kayıların önlenmesinde insan ile yaşam arasında bir köprü olan eğitim kurumları; toplumdaki değişme ve gelişme hızına uygun bir şekilde insanın eğitilmesi ve yetiştirilmesine cevap verebilmelidirler (Taymaz, 1995: 1). Eğitim kurumları (okul), böyle bir ortamda insanın çevresinde sürekli oluşan değişiklikleri karşılamak, birey davranışlarını değiştirmek ve yeni davranışlar kazandırmakla yükümlüdür. $\mathrm{Bu}$ nedenle okulun, hem çevredeki gelişmelere uyum sağlayacak, hem de çevrede beklenen değişmeleri oluşturabilecek yeterliliğe ulaştırılması gerekmektedir (Başaran, 1978: 13).

Eğitim yoluyla birey/bireylerde istendik davranışların kazandırılması arzulanır. Bununla birlikte eğitilmeye çalışılan bir insanda davranış değişikliğinin kendi yaşantısı yolu ile oluşabilmesi için bireyin beklenen davranışı göstermeyi istemesi, benimsemesi, 
algılaması, bireyin bedensel ve zihinsel olarak davranışları göstermeye yeterli ve elverişli olması gerekir. Ayrıca uygun öğrenim ortamı olması ve bireye istendik davranış oluşturulmasını sağlayabilecek yeterli düzeyde bilgi, beceri ve tutumun kazandırılması gerekir (Başaran, 1982: 6).

Eğitim hizmetlerinin üretilmesi, madde ve insan gücünün yönlendirilmesi bağlamında önem arz eden eğitim yönetiminin deney ve sonuçlarını esas kabul eden bilimsel düşüncelere dayandırılması gerekir. Bununla birlikte sosyal bilimler alanında, konunun insan olması ve insanın duygu, düşünce, davranış, eğilim ve yaşam tarzları bakımından birbirinden farklılaşması ve aynı kişinin zamana ve zemine göre bile farklı davranabilmesi bu durumu zorlaştırır (Arslanargun, 2007).

Eğitim Yönetimi, eğitimle ilgili kuruluş ve okulların amaçlarına ulaşabilmeleri için insan, para ve araç-gereçlerin en etkin ve verimli biçimde yerleştirilmesini ya da kullanılmasını inceleyen bilim dalıdır. Eğitim yönetimi bir toplumun eğitim ihtiyaçlarını karşılamak amacıyla oluşturulan eğitim sisteminin ve eğitim sisteminde yer alan bütün örgütlerin yönetimini kapsamaktadır (Hoca, 2007).

21. yüzyılda artan küresel rekabet içerisinde servis sağlayıcılar müşterilerin memnuniyetini artırabilecek nitelikli hizmetler sunmak zorundadırlar. Bu durum müşteriler için daha fazla değer yaratma, rakip kurumlara karşı rekabet oluşturma, fırsat yaratma ve müşteri memnuniyeti ortaya çıkmaktadır (Asogwa, 2014). Bu süreçte hizmet sektörlerindeki büyümeye paralel olarak eğitim sektörü de büyümektedir. Bununla birlikte eğitim hizmetleri sektöründe en önemli konulardan bir tanesini de eğitim hizmetlerinin pazarlanması oluşturmaktadır (Okumuş ve Duygun, 2008). Modern eğitimin kavramları ise ilerleme, eğitim alanındaki iyimserlik ve yeni yöntemler olarak gösterilmektedir (Aslanargun, 2007).

Eğitim ve öğretimdeki hızlı teknolojik değişimler ve gelişen bilgi toplumunun sonucu olarak üniversiteler, müşteri (öğrenci) merkezli bir yaklaşıma gereksinim duyarlar ve kaliteli öğretimin yanısıra öğretimle ilgili olmayan diğer hizmetlere de yoğunlaşmak zorunda olan kurumlardır (Petruzzellis vd., 2006).

Yükseköğretim kurumlarının güçlü ve zayıf yönlerinin ortaya çıkarılmasında kalite ölçümleri yapılması gerekmektedir. Bu ölçümler kaynakların (yatırımların) optimal dağılımının sağlanmasında ve yükseköğretim kurumlarının zayıf yönlerinin kuvvetlenmesi açısından önem arz eder. Bu kapsamda yükseköğretim kurumlarında kalite güvence sistemi oluşturulması ve akreditasyon sürecine geçilmesi gerekmektedir (Elmacı vd., 1999: 111). Bir ülkenin kalkınmasında önemli bir dinamik olarak eğitim hizmetlerinin pozitif dışsal ekonomi yaratabilmesi bağlamında, yükseköğretim hizmetlerinin iyi sonuçlar elde edebilmesi için kalitesi arttırmalıdır (Sözer vd., 2002: $42)$.

Bir toplumda yaşam standartlarının önemli göstergelerinden birisi de hizmet sektöründe kalite ve verimliliğin artırılmasıdır. Bu bağlamda üniversitelere önemli görevler düşmektedir. Üniversiteler, öğrencilerin istek ve ihtiyaçlarına uygun hizmetlerin tasarlanması ve sunulması, öğrencilerin derslere uyum kabiliyetini ve 
katılımını sağlayabilecek bilgi ve becerileri benimsemesi ve öğrencilerinin üniversitelerine bağlılıklarını artıracak çabalara yönelmesi gerekmektedir. Bu boyutuyla öğrencilerin "algılanan hizmet kalitesinin tespit edilmesi" son derece önemli bir konudur (Özgül ve Devebakan, 2005).

Yükseköğretimde kalite yönetimi; fiziki altyapı (bina, spor tesisleri vb.), akademik altyapı (laboratuvar, kütüphane, dokümantasyon, iletişim, bilgi işlem vb.), eğitim-öğretim planı, sınav ve değerlendirme sistemi, akademik/idari personel temin ve geliştirme sistemi, araştırma ve yayınlar, kurumsal gelişme planı (stratejik planlama), sektörel iş birliği ile ilişkilendirilmektedir (Elmacı vd., 1999: 116).

Bir üniversitenin sahip bulunduğu marka itibarı ve uluslararası tanınırlığı iş başvurularında avantaj sağlar hale gelmiştir. Bu süreçte mezun olan öğrencilerinin kazanımları, yayın sayısı, icat, buluş, araştırma, öğretim elemanlarının kalitesi, fiziksel yapı, somut araç-gereçlerinin görünümü ve yeterliliği, kütüphane olanakları, bilgisayar, yabancı dil hizmetleri ve internet ortaminda web sitelerinin üniversite ile ilgi pozitif farklılıklar ortaya koyabilmesi gibi özellikler yükseköğretim kurumunun marka itibarinin göstergeleri haline gelmiştir Bununla birlikte bir yükseköğretim kurumunun faaliyetini devam ettirdiği yörede şu roller perspektifinde hizmet vermesi beklenilmektedir (Gürbüz ve Ergülen, 2008: 157):

- Bilgi, kültür, eğitim ve öğretimin gelişimine katkıda bulunma,

- Öğrencilerini bilgi, yetenek ve becerilerle donatarak gelişimlerinin sağlama,

- Siyasi, sosyal, ekonomik hareketlilik ve katkı sağlama,

- Nüfusun sayı ve niteliğinin yükselmesini sağlama,

- Kişi başına milli geliri artırma,

- Güven sağlama,

- Bilimsel buluş ve yenilik, araştırma ve geliştirme faaliyetlerini itekleyici motor güç olma,

- Yörenin tarihine ve kültürüne katkı sağlama.

$\mathrm{Bu}$ beklentiler doğrultusunda yükseköğretim kurumlarında öğrencilere sunulan hizmetlerin, öğrencilerin istek ve ihtiyaçlarına uygun olarak tasarlanması ve sunumu gerekmektedir. Bu durum öğrencilerin derslere uyum kabiliyetini, katılımını ve verilen bilgi ve becerilerin benimsenmesini ve üniversite bağlılıklarını artırabilir. SERVQUAL gibi yöntemlerle hizmetlerin algılanma biçiminin ortaya konulması, aradaki algılama farklılıklarının giderilmesi ve kalite düzeyinin yükseltilmesi bakımından oldukça önemlidir (Özgül ve Devebakan, 2005).

Yükseköğretim kurumlarının ideal fiziksel koşullara ulaştırılması, çalışanları arasında iletişim ve takım çalışması anlayışı fikrinin benimsetilmesi, verimli çalışma için motivasyonun artırılması, teknolojik gelişmelerin takip edilmesi ve kurumlarda güler yüzlü bir çalışma ortamı için "ben" yerine "biz" felsefesinin yerleştirilmesinde, "toplam kalite yönetimi" ideal bir yönetim tarzı olarak gösterilmektedir (Sözer vd., 2002: 63). Bununla birlikte yükseköğretim kalite unsurları ve müşterileri Tablo 1'de sunulan biçimde ilişkilendirilmektedir (Çavdar, 2009: 106-107): 
Tablo 1. Yükseköğretimde Kalite Unsurları ve Müşterileri

\begin{tabular}{|c|c|c|}
\hline & Yükseköğretimde Kalite Unsurları & Müşterileri \\
\hline $\begin{array}{l}\text { Somut } \\
\text { Unsurlar }\end{array}$ & $\begin{array}{l}\text { Yeterli tesis ve ekipmanlar, } \\
\text { Modern tesis ve ekipmanlar, } \\
\text { Ulaşım kolaylığı, } \\
\text { Hoş görsel çevre, } \\
\text { Barınma ve spor gibi destekleyici hizmetler (barınma, spor }\end{array}$ & $\begin{array}{c}\text { Öğrenci } \\
\text { Akademik Personel }\end{array}$ \\
\hline Yeterlilik & $\begin{array}{l}\text { Yeteri kadar akademik personel, } \\
\text { Yetenekler ve teorik bilgi, } \\
\text { Pratik bilgi, } \\
\text { Güncellik, } \\
\text { İletisim ve öŏretme hecerisi }\end{array}$ & $\begin{array}{c}\text { Öğrenci } \\
\text { Akademik Personel }\end{array}$ \\
\hline Tutum & $\begin{array}{l}\text { Öğrenci ihtiyaçlarını anlama, } \\
\text { Yardımcı olmaya isteklilik, } \\
\text { Danışmanlık ve yardım için ulaşılabilirlik, } \\
\text { Bireysel ilgi. }\end{array}$ & Öğrenci \\
\hline İçerik & $\begin{array}{l}\text { Öğrencilerin gelecekteki işlerine uygun müfredat, } \\
\text { Geçerlilik, } \\
\text { Kapsayıcı beceri ve temel bilgiler, } \\
\text { Tamamlayıcı nitelikte bilgisayar kullanımı, } \\
\text { Takım çalışması ve iletişim becerisi, } \\
\text { Disiolinler arası bilgi ve esneklik. }\end{array}$ & $\begin{array}{l}\text { Öğrenci } \\
\text { Akademik Personel } \\
\text { Çalışanlar }\end{array}$ \\
\hline Sunum & $\begin{array}{l}\text { Etkili sunum, } \\
\text { Yerindelik ve serilik, } \\
\text { Tutarlılık, } \\
\text { Tarafsız yapılan sınavlar, } \\
\text { Öğrenci geribildirimleri, } \\
\text { Öğrenci cesaretlendirilmeleri, }\end{array}$ & Öğrenci \\
\hline Güvenilirlik & $\begin{array}{l}\text { Güvenilirlik, } \\
\text { Ödüller verme, } \\
\text { Sözünü tutma, } \\
\text { Problemleri çözme ve şikâyet değerlendirme. }\end{array}$ & $\begin{array}{l}\text { Öğrenci } \\
\text { Akademik Personel } \\
\text { Çalışanlar }\end{array}$ \\
\hline
\end{tabular}

Kaynak: Çavdar, 2009: 106-107'den uyarlanmıştır.

Bir ülkede kaliteli bir eğitimden söz edebilmek için eğitim hizmetlerini alan öğrencilerin beklentilerini ve algılamalarını çok iyi anlamak gerekir. Bu şekilde eğitim hizmetlerine ilişkin beklentiler ve algıların kalitesi artırılabilir (Okumuş ve Duygun, 2008). Bu nedenle artan rekabet ortamında yükseköğretim kurumları, eğitim ihtiyacı kapsamında kendilerine başvuran öğrencilerinin sadece eğitim kalitesini değil, öğrencilerine sunduğu destek hizmetlerinde de öğrencilerin tatmin seviyelerini yükseltmenin yollarını aramalıdırlar (Tosun ve Başgöze, 2015: 144).

Yükseköğretim kurumları kalite güvence sistemi kapsamında kurumdan hizmet alan tüm tarafların asgari ihtiyaçlarını karşılayacak değerleme ve gözden geçirme faaliyetlerine önem vermeli, kaliteli hizmetler sunmalı, güven verici denetleme gerçekleştirmelidir. Bu kapsamda üniversitelerin bilgi ve bilim hizmeti üretimi sürecinde kalite yönetim felsefesinden yararlanması, nitelikli ve kaliteli bireylerin yetiştirilmesi açısından çok önemli bir konudur. $\mathrm{Bu}$ nedenle yükseköğretim kurumlarının kalite yeterliliklerinin tespiti ve geliştirilmesi çalışmaları önem arz etmektedir (Karahan, 2013: 1). 
Bir toplumda yaşam standartlarının önemli göstergelerinden birisi de hizmet sektöründe kalite ve verimliliğin artırılmasıdır. Bu bağlamda üniversitelere önemli görevler düşmektedir. Üniversiteler, öğrencilerin ihtiyaç ve isteklerine uygun hizmetlerin sunulması ve tasarlanması, öğrencilerin derslere uyum kabiliyetini ve katılımını sağlayabilecek bilgi ve becerileri benimsemesi ve üniversiteye bağlılıklarını artıracak çabalara yönelmelidir. Bu boyutuyla öğrencilerin "algılanan hizmet kalitesinin tespit edilmesi" son derece önemli bir konudur (Özgül ve Devebakan, 2005).

Yükseköğretim kurumlarında artan rekabet ve yüksek hizmet kalitesi beklentisi nedeniyle verilen hizmet kalitesinin yeniden değerlendirilmesine yönelik çalışmalar sayıca artmaktadır. Bu çalışmalar eğitim planlarının verimliliği ve eğitim programlarının geliştirilmesine dönük olup; eğitimde çeşitlilik, tesislere erişim kolaylığı, öğretmen öğrenci etkileşimi, öğrenci kalitesini arttırma, eğitim sürecini iyileştirme, akademik kalite, teknoloji ve öğretim deneyimi üzerinde yoğunlaşmaktadır (Cardona ve Bravo, 2012). Türkiye'de de son dönemlerde hizmet kalitesi ölçümlerine sağlık ve eğitim sektöründe sıkça başvurulmaktadır. Ancak bu çalışmalarda hizmet kalitesinin hangi boyutlar altında değerlendirilmesi gerektiği konusunda tartışmalar sürmekte ve Tablo 2'de öngörülen bileşenler öne çıkartılmaktadır.

Tablo 2. Yükseköğretimde Hizmet Kalitesi Bileşenleri ile İlgili Çalışmalar

\begin{tabular}{|c|c|}
\hline Yükseköğretimde Hizmet Kalitesi Bileşenleri & İlgili Çalışmalar \\
\hline $\begin{array}{l}\text { Hizmet kalitesi ölçümünde katılımcıların sayısını artırma adına } \\
\text { hediyeler verme, } \\
\text { Yalın ve kısa sorularla hizmet kalitesi ölçümü, } \\
\text { Düzenli aralıklarla anket ölçümü yapılması ve gelişmelerin izlenmesi, } \\
\text { Çalışma sonuçlarının üniversite yönetimleri ile paylaşılması. }\end{array}$ & Bulgan ve Gürdal (2005) \\
\hline $\begin{array}{l}\text { Öğretim elemanlarının bilgili ve konusuna hakim olması Güvenilir, } \\
\text { doğru bilginin aktarılması, }\end{array}$ & Özgül ve Devebakan, (2005) \\
\hline $\begin{array}{l}\text { Hizmette yeterlilik, } \\
\text { Heveslik }\end{array}$ & Yilmaz vd. (2007) \\
\hline $\begin{array}{l}\text { Yükseköğretim kurumlarına yönelik olumlu bir tutum geliştirilmesi, } \\
\text { Yükseköğretim kurumlarının yeterli öğretim elemanına ve fiziksel } \\
\text { olanaklara sahip bulunması, } \\
\text { Yükseköğretim kurumalarının sosyokültürel konularda yeterliliğini } \\
\text { artırması, } \\
\text { Yükseköğretim kurumunda öğretilen bilgilerin ekonomiyi olumlu } \\
\text { etkilemesi, } \\
\text { Yükseköğretim kurumlarının kurum içi ve kurum dışı geri bildirime } \\
\text { dayalı iletişim kurması, } \\
\text { Yükseköğretim kurumlarının çağın gereklerine göre kendilerini } \\
\text { yenileştirmeleri. }\end{array}$ & Gürbüz ve Ergülen (2008) \\
\hline
\end{tabular}


Tablo 2. Yükseköğretimde Hizmet Kalitesi Bileşenleri ile İlgili Çalışmalar (Devamı)

\begin{tabular}{|c|c|}
\hline Yükseköğretimde Hizmet Kalitesi Bileşenleri & İlgili Çalışmalar \\
\hline $\begin{array}{l}\text { Memnuniyet, } \\
\text { İmaj, } \\
\text { Tavsiye, } \\
\text { Sadakat, } \\
\text { Fiziksel özellikler, } \\
\text { Destek hizmetleri, } \\
\text { Uluslararasılaşma, } \\
\text { Akademik personel, } \\
\text { İdari personel. }\end{array}$ & Tayyar ve Dilşeker (2012) \\
\hline $\begin{array}{l}\text { Ĕgitimde çeşitlilik, } \\
\text { Tesislere erişim kolaylığı, } \\
\text { Öğretmen öğrenci etkileşimi, } \\
\text { Öğrenci kalitesini arttırma, } \\
\text { Eğitim sürecini iyileştirme, } \\
\text { Akademik kalite, } \\
\text { Teknoloji } \\
\text { Öğretim deneyimi. }\end{array}$ & Cardona ve Bravo (2012) \\
\hline $\begin{array}{l}\text { Öğrencilerin görüşlerine önem verme, } \\
\text { Şikayetleri dinlenme, } \\
\text { Şikayetleri çözüme kavuşturma, }\end{array}$ & Görmüş vd. (2013) \\
\hline $\begin{array}{l}\text { Ortak kullanım alanlarının temizliği, } \\
\text { Çevre düzenleme hizmetleri, } \\
\text { Öğrenci topluluklarının sosyal aktiviteleri, } \\
\text { Etkinlikler kapsamında öğrencilerle iletişimi artırma, Hizmet } \\
\text { personelinin eğitimlerle yeterli düzeye getirme, } \\
\text { Mezun olan öğrencilere kariyer desteği sağlanması. }\end{array}$ & Karahan (2013) \\
\hline $\begin{array}{l}\text { Tesis ve donanımlar, } \\
\text { Akademik ve idari personel hizmetleri, } \\
\text { Derslerin içeriği, } \\
\text { Sınavlar. }\end{array}$ & Cevher (2015) \\
\hline
\end{tabular}

Yükseköğretim kurumlarında Öğrenci İşleri Daire Başkanlığı hizmetlerine yönelik önceki çalışmalarda (Sözer vd., 2002; Görmüş vd., 2013; Hayırsever, 2014; Tosun ve Başgöze, 2015) ise öğrencilerin genel tatmin düzeylerinin düşük olduğu yönündedir. Öğrenci belgeleri ve diplomaların zamanında hazırlanmaması ve notların girilmesindeki aksaklıklar ana şikâyet nedenleri gösterilmektedir. Öğrencilerin okuduğu sınıf düzeyi arttıkça kalite algılarının düştüğü, ziyaret sıklığı azaldıkça kalite algılarının arttı̆̆ı yönündedir. SERVQUAL ölçeği boyutlarında ise "güvenilirlik" en kaliteli "cevap verebilme" boyutu ise en kalitesiz boyut olarak gösterilmektedir.

\section{Metodoloji}

\subsection{Araştırma Alanı}

Türkiye'de Batı Karadeniz Bölgesi içerisinde Karabük Merkez ilçede yer alan Karabük Üniversitesi, il için demir ve çelik üretiminden sonra ikinci önemli kalkınma hamlesi olarak 2007 yılında kurulmuştur. Karabük Üniversitesi bünyesinde 2015-2016 eğitim dönemi itibariyle 4 enstitü 14 fakülte, 4 yüksekokul ve 8 meslek yüksekokulu bulunmaktadır. Bu eğitim birimlerinde hali hazırda 47.014 öğrenci öğrenim 
görmektedir (araştırmanın gerçekleştirildiği 2014-2015 eğitim-öğretim döneminde öğrenci sayısı 41.341 'dir). Bu öğrenciler, kente sosyal ve ekonomik katkı sağlayan birer dinamik olarak kabul edilmektedir.

\subsection{Araştırmanın Amacı}

Eğitim hizmeti veren kurum ve kuruluşlarda öğrenci başarısını etkileyen olumsuzlukların en aza indirilmesi, eğitim başarısını artıran önemli göstergelerden bir tanesini oluşturur. Eğitim hizmetlerinde başarı ortak hareket edebilen ve bütünlük arz eden bir sistemin gerekliliğini zorunlu kılar. Bu sistem birçok aktörün (yöneticiler, eğitmenler, idari personel, öğrenciler vd.) ortak hareket etmesini gerektirir. Bununla birlikte bu aktörlerin sunmuş oldukları hizmetlerin kalitesinin ölçülmesi ve ölçüm sonuçları çerçevesinde iyileştirici önemlere odaklanılması eğitimde öğrenci başarı düzeyini doğrudan etkileyebilmektedir.

$\mathrm{Bu}$ araştırma, üniversiteler bünyesinde Öğrenci İşleri Daire Başkanlığı kapsamında verilen hizmetlere katkı sağlamak düşüncesiyle kurgulanmıştır. Araştırmada Karabük Üniversitesi Öğrenci İşleri Daire Başkanlığı'ndan hizmet alan üniversite öğrencilerinin algılanan ve beklenen hizmet kalitesi algıları arasında SERVQUAL yöntemine kapsamında ölçümlenmesi amaçlanmaktadır. Bu doğrultuda araştırma problemi “Karabük Üniversite öğrencilerinin Öğrenci İşleri Daire Başkanlığı tarafından sunulan hizmetlere yönelik SERVQUAL skoru ne düzeydedir" olarak belirlenmiştir.

\subsection{Araştırmanın Önemi}

Müşteri memnuniyeti kapsamında hizmet satın almayı düşünen mevcut ve potansiyel müşterilerin sosyal ve psikolojik güdülerin öğrenilmesi gerekmektedir. Somaratna ve Peiris (2011), yükseköğretim kurumlarının gelişen ve değişen dijital çevre perspektifinde rekabet edebilme gücünü artırıcı eylemlere yönelmesine dikkat çekmektedir. Bu anlamda yükseköğretim kurumlarının rekabet gücünü artırabilmesi adına kurum içi ve kurum dişı çevresini iyi analiz etmeleri gerekmektedir. Kurum içi çevre analizleri kapsamında hizmet kalitesi ölçümleri önemli bir araçtır. Bu araştırma, öğrenci memnuniyeti perspektifinden Karabük Üniversitesi Öğrenci İşleri Daire Başkanlığı hizmetlerini test etme ve öğrenci işleri birimine yönelik öneriler sunabilme adına önem arz etmektedir.

\subsection{Araştırmanın Sınırlılıkları}

Üniversite öğrencilerinin, Öğrenci İşleri Daire Başkanlığı tarafından sunulan hizmetlerin kalite algıları ile beklentileri arasındaki ilişkinin test edildiği bu çalışmada sinırlılıklar aşağıdaki şekilde ön görülmüştür:

-Araştırma, Karabük Üniversitesi Öğrenci İşleri Daire Başkanlığg'ndan hizmet alan öğrencilere yönelik hazırlanan anket ölçeği ile sınırlıdır.

-Araştırma, Karabük Üniversitesi'nde 2014-2015 eğitim ve öğretim yılında öğrenim görmekte olan ön lisans ve lisans öğrencilerinin görüşleri ile sınırlıdır. 


\subsection{Araştırmanın Yöntemi}

$\mathrm{Bu}$ araştırma Yükseköğretim kurumları Öğrenci İşleri Daire Başkanlığından hizmet almakta olan öğrencilerinin algilanan ve beklenen hizmet kalitesi arasındaki farklığı belirleyemeye yönelik olup tarama modeli üzerine kurulu nicel betimsel bir araştırmadır.

\subsection{Evren ve Örneklem}

Araştırmanın evreni; Karabük Üniversitesi kapsamında 2014-2015 öğretim yılında öğrenim gören 41.341 üniversite öğrencisi olarak kabul edilmiştir. Araştırma evreninin genişliği çerçevesinde örnekleme başvurulmuştur. Örneklem büyüklüğü 384 (güven aralığı \%95 ve Z değeri 1,96) olarak belirlenmiştir. Çalışma, 507 katılımcı üzerinden gerçekleştirilmiştir.

\subsection{Verilerin Toplanması ve Analizi}

Araştırma verilerin toplanmasında anket tekniğine başvurulmuştur. Araştırma için birincil verilerine ulaşmak için Yılmaz ve arkadaşları (2007) tarafından gerçekleştirilen SERVQUAL araştırma ölçeğinden faydalanılmış ve anket soruları oluşturulmuştur. Anket, basit tesadüfi örnekleme yöntemi kapsaminda yüz yüze görüşme tekniği ile Öğrenci İşleri Daire Başkanlığından hizmet alan üniversite öğrencilerine, Eylül 2014 ve Haziran 2015 dönemi içerisinde uygulanmıştır. Anket ölçeği için Cronbach Alpha değeri 0,96 olarak tespit edilmiştir.

\section{Araştırma Bulguları}

Araştırmada örnek alan olarak seçilen Karabük Üniversitesi Öğrenci İşleri Daire Başkanlığ1 tarafından sunulan hizmetlere yönelik öğrencilerin algılanan ve beklenen hizmet kalitesine yönelik güvenilirlik, heveslilik, fiziksel özellikler, empati ve güven beklentilerine ait SERVQUAL skorları Tablo 3 gösterilen biçimde tespit edilmiştir. 
Tablo 3. Karabük Üniversitesi Öğrenci İşleri Daire Başkanlığı Hizmetleri SERVQUAL Skorları

\begin{tabular}{|c|c|c|c|c|c|c|}
\hline \multirow{2}{*}{\multicolumn{2}{|c|}{ Boyutlar/Yargılar }} & \multirow{2}{*}{$\begin{array}{l}\text { Algilanan } \\
\text { Hizmet } \\
\text { Kalitesi } \\
\bar{x}\end{array}$} & \multirow{2}{*}{$\begin{array}{c}\text { Beklenen } \\
\text { Hizmet } \\
\text { Kalitesi } \\
\bar{x}\end{array}$} & \multicolumn{3}{|c|}{ SERVQUAL Skoru } \\
\hline & & & & Fark & Boyut & Toplam \\
\hline \multirow{4}{*}{ 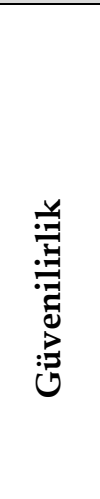 } & $\begin{array}{l}\text { İdeal Öğrenci İşleri Dairesi kayıtların ve } \\
\text { bilgilerin hatasız tutulmasında çok }\end{array}$ & 3,34 & 3,85 & $-0,51$ & \multirow{4}{*}{$-0,53$} & \\
\hline & $\begin{array}{l}\text { İdeal Öğrenci İşleri Dairesi hizmetlerini } \\
\text { daha önceden söyledikleri zaman içinde } \\
\text { verir. }\end{array}$ & 3,29 & 3,82 & $-0,53$ & & \\
\hline & $\begin{array}{l}\text { İdeal Öğrenci İşleri Dairesi çalışanları } \\
\text { verdiği sözü zamanında yerine getirir. }\end{array}$ & 3,28 & 3,83 & $-0,55$ & & \\
\hline & $\begin{array}{l}\text { İdeal Öğrenci İşleri Dairesi hizmetlerini } \\
\text { ilk seferde ve doğru olarak verir. }\end{array}$ & 3,26 & 3,79 & $-0,53$ & & \\
\hline \multirow{3}{*}{ : } & $\begin{array}{l}\text { İdeal öğrenci işleri yenilik, gelişim ve çağa } \\
\text { uyum konusunda topluma önderlik } \\
\text { yapmaya isteklidir. }\end{array}$ & 3,32 & 3,78 & $-0,46$ & \multirow{3}{*}{$-0,46$} & \\
\hline & $\begin{array}{l}\text { İdeal Öğrenci İşleri Dairesi hiç bir zaman } \\
\text { öğrenci isteklerine cevap veremeyecek } \\
\text { kadar meşgul değildir. }\end{array}$ & 3,31 & 3,75 & $-0,44$ & & \\
\hline & $\begin{array}{l}\text { İdeal Öğrenci İşleri Dairesi çalışanları } \\
\text { öğrenciye yardım etmeye gönüllüdür. }\end{array}$ & 3,27 & 3,76 & $-0,49$ & & \\
\hline \multirow{3}{*}{ 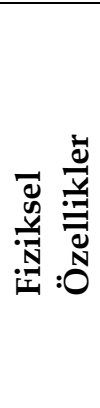 } & $\begin{array}{l}\text { İdeal Öğrenci İşleri Dairesinin çalışanları } \\
\text { yetenekli, yeterli, temiz ve düzgün } \\
\text { görünüşlüdür. }\end{array}$ & 3,41 & 3,86 & $-0,45$ & \multirow{3}{*}{$-0,36$} & $-0,49$ \\
\hline & $\begin{array}{l}\text { İdeal Öğrenci İşleri Dairesinde hizmet } \\
\text { verirken kullanılan malzemeler (araç- } \\
\text { gereçler) göze hoş görünür. }\end{array}$ & 3,35 & 3,76 & $-0,41$ & & \\
\hline & $\begin{array}{l}\text { İdeal Öğrenci İşleri Dairesi modern } \\
\text { görünüşlü donanma sahiptir. }\end{array}$ & 3,32 & 3,54 & $-0,22$ & & \\
\hline \multirow{2}{*}{ 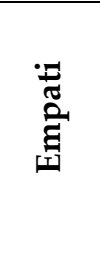 } & $\begin{array}{l}\text { İdeal Öğrenci } \\
\begin{array}{l}\text { İşleri Dairesi öğrenciyle } \\
\text { kişisel olarak } \\
\text { sahiptir. }\end{array}\end{array}$ & 3,10 & 3,76 & $-0,66$ & \multirow{2}{*}{$-0,65$} & \\
\hline & $\begin{array}{l}\text { İdeal Öğrenci İşleri Dairesi öğrencilerinin } \\
\text { taleplerini her şeyin üstünde tutar. }\end{array}$ & 3,05 & 3,68 & $-0,63$ & & \\
\hline \multirow{2}{*}{ 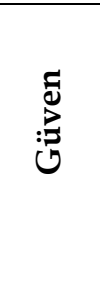 } & $\begin{array}{l}\text { İdeal Öğrenci İşleri Dairesinde öğrenci, } \\
\text { personel ile olan ilişkilerinde kendilerini } \\
\text { güvende hisseder. }\end{array}$ & 3,33 & 3,72 & $-0,39$ & \multirow{2}{*}{$-0,43$} & \\
\hline & $\begin{array}{l}\text { İdeal Öğrenci İşleri Dairesi personelinin } \\
\text { davranışları öğrencilerde güven duygusu } \\
\text { uyandırır. }\end{array}$ & 3,30 & 3,77 & $-0,47$ & & \\
\hline
\end{tabular}


Öğrenci İşleri Daire Başkanlığı tarafından sunulan hizmetlerin kalitesini belirlemeye yönelik ifadeler ayrı ayrı incelendiğinde; Güvenilirlik boyutunda öğrencilerinin algılanan $(\bar{x}=3,34)$ ve beklenen $(\bar{x}=3,85)$ hizmet kalitesi ortalamasında en yüksek ortalama "ideal öğrenci işleri dairesi kayıtların ve bilgilerin hatasız tutulmasında çok titizdir" ifadesinde gerçekleşmiştir. SERVQUAL skorunda ise en büyük fark $(-0,55)$ "ideal öğrenci işleri dairesi çalışanları verdiği sözü zamanında yerine getirir" ifadesinde çıkmıştır. Bu durumlar kapsamında öğrencilerin kayıtların hatasız tutulmasını önemsedikleri şeklinde yorumlanabilir. Bununla birlikte hizmet kalitesi güvenilirlik boyutuna ilişkin dört ifadenin SERVQUAL skorlarının hepsinin negatif olması, Karabük Üniversitesi Öğrenci İşleri Daire Başkanlığı'nın güvenilirlik beklentilerini karşılayamadığı söylenebilir.

Heveslilik boyutunda öğrencilerinin algılanan $(\bar{x}=3,32)$ ve beklenen $(\bar{x}=33,78)$ hizmet kalitesi ortalamasında en yüksek ortalama "ideal öğrenci işleri yenilik, gelişim ve çağa uyum konusunda topluma önderlik yapmaya isteklidir" yargısında ortaya çıkmıştır. SERVQUAL skorunda ise en büyük fark $(-0,46)$ " ideal öğrenci işleri dairesi çalışanları öğrenciye yardım etmeye gönüllüdür" yargısında gerçekleşmiştir. Bu yargılar çerçevesinde öğrencilerin çağa uyum, yenilik ve gelişim konusunu önemsediklerini söylemek mümkündür. Öğrenci işleri hizmet kalitesi heveslilik boyutunda da üç ifadenin SERVQUAL skorlarının hepsinin negatif olması $(-0,46)$ kapsamında Karabük Üniversitesi Öğrenci İşleri Daire Başkanlığı'nın heveslilik beklentilerini karşılamada yetersiz kaldığı şeklinde yorumlanabilir.

Kamu sektöründe sunulan hizmetler sadece gereksinimleri karşılama ile ilişkilendirilmemeli, gereksinimleri önceden keşfetme, öncelik oluşturma ve kaynakları etkin kullanamaya yönelik olmalıdır. Ayrıca siyasi kısıtlar içerisinde hesap verebilir, adil ve tarafsız olmalıdır (Gürbüz ve Ergülen, 2008: 5). Bu perspektifte sunulan hizmetlere yönelik güvenilirlik, heveslilik, fiziksel imkanlar, empati ve güven boyutları ile SERVQUAL ölçümleri kamu sektörünün önemli bir birimi olan yükseköğretim kurumları için kaçınılmaz bir gerekliliktir.

Fiziksel özellikler boyutunda öğrencilerinin algılanan $(\bar{x}=3,41)$ ve beklenen $(\bar{x}=3,86)$ hizmet kalitesi ortalamasında en yüksek ortalamaya sahip yarg1 "ideal öğrenci işleri dairesinin çalışanları yetenekli, yeterli, temiz ve düzgün görünüşlüdür" ifadesinde ortaya çıkmıştır. Bu yargıyı "ideal öğrenci işleri dairesinde hizmet verirken kullanılan malzemeler (araç-gereçler) göze hoş görünür" yargısı izlemiştir. Fiziksel özelliklere ilişkin SERVQUAL skorunda ise en büyük fark $(-0,45)$ "ideal öğrenci işleri dairesinin çalışanları yetenekli, yeterli, temiz ve düzgün görünüşlüdür" ifadesinde çıkmıştır. Bu durumlar kapsamında öğrencilerin fiziksel özellikler boyutunda fiziki araç ve gereçlerden daha ziyade personelin görünüşünü önemsemesi dikkat çekicidir. Bununla birlikte fiziksel özelliklere ilişkin üç ifadenin SERVQUAL skorlarının hepsinin negatif olması $(-0,36)$ kapsamında Karabük Üniversitesi Öğrenci İşleri Daire Başkanlığı'nın fiziksel özellik beklentilerini karşılayamadığı düşünülebilir. 
Empati boyutunda öğrencilerinin algılanan $(\bar{x}=3,10)$ ve beklenen $(\bar{x}=3,76)$ hizmetlere yönelik hizmet kalitesi ortalamasında en yüksek ortalama "ideal öğrenci işleri dairesi öğrenciyle kişisel olarak ilgilenecek çalışanlara sahiptir" yargısında ortaya çıkmıştır. SERVQUAL skorunda da bu yargı $(-0,66)$ önde bulunmaktadır. Bu yargı kapsamında öğrencilerin kişisel olarak ilgiyi hizmet taleplerinde önemsediklerini söylemek mümkündür. Öğrenci işleri hizmet kalitesi ilgi boyutunda da iki ifadenin SERVQUAL skorlarının negatif olması $(-0,65)$ kapsamında Karabük Üniversitesi Öğrenci İşleri Daire Başkanlığı'nın empati beklentilerini karşılamada yetersiz kaldığı şeklinde değerlendirilebilir.

Güven boyutunda öğrencilerinin algılanan hizmet kalitesi ortalaması $(\bar{x}=3,33)$ ve beklenen hizmet kalitesi ortalaması $(\bar{x}=3,77)$ olarak belirlenmiştir. Algılanan hizmetlere yönelik hizmet kalitesi ortalamasında en yüksek ortalama "ideal öğrenci işleri dairesinde öğrenci, personel ile olan ilişkilerinde kendilerini güvende hisseder" yargısında ortaya çıkmıştır. Beklenen hizmetlere yönelik hizmet kalitesi ortalamasında ise en yüksek ortalama "ideal öğrenci işleri dairesi personelinin davranışları öğrencilerde güven duygusu uyandırır" yargısında meydana gelmiştir. Öğrenci işleri hizmet kalitesi güven boyutunda öğrencilerin, personelin güvenli davranışlarını önemsediği söylenebilir. Güven boyutuna ilişkin toplam SERVQUAL skorlarının negatif olması $(-0,43)$ kapsamında Karabük Üniversitesi Öğrenci İşleri Daire Başkanlığı'nın güven beklentilerini karşılamada yetersiz kaldığı söylenebilir.

\section{SONUÇ VE TARTIŞMA}

Fiziksel olarak sahip olunamayan bir iş, hareket veya çabayı içeren soyut mamuller olarak görülen hizmetler (Üner, 1994) için mevcut ve potansiyel müşterilerin hizmeti almadan önceki beklenti/beklentilerinin öğrenilmesi kaçınılmazdır. Bu anlamda sunulan hizmetler kapsamında müşteri beklentilerini belirleyebilmek amacıyla hizmet kalitesi ölçümleri önem arz etmektedir. Özellikle, yüksek düzeyde eğitim-öğretim, bilimsel araştırma ve yayın yapan ve fakülte, enstitü, yüksekokul, bölüm, anabilim dalı, anasanat dalı, bilim dalı, sanat dalı, araştırma ve uygulama merkezlerinden oluşan yükseköğretim kurumlarında hizmet kalitesi ölçümlemeleri küresel dünyada rekabet edebilmede önemli bir gerekliliktir.

Yükseköğretim kurumları tarafından sunulan hizmetler çok geniş bir yelpazeyi kapsar. Bu yelpazede içerisindeki hizmetlerden bir tanesini Öğrenci İşleri Dairesi Başkanlığı hizmetleri oluşturur. Yükseköğretim öğrencilerin yeni kayıt, kabul ve ders durumları ile ilgili gerekli işleri yapmak, mezuniyet, kimlik, burs, mezunların izlenmesi işlemlerini yürütmek, verilecek diğer benzeri görevleri yerine getiren olarak Öğrenci İşleri Dairesi Başkanlığı tüm öğrenciler tarafından sıkça hizmet talep edilen önemli bir birim konumundadır. Bu durum kapsamında Öğrenci İşleri Dairesi Başkanlığ1 hizmetlerinin hizmet kalitesi ölçümleri kapsamında belirli zamanlarda ölçülmesi ve öğrencilerden geri bildirim alınması önemli bir gerekliliktir. Çünkü geçmiş dönemlerde öğrenci işleri birimine yönelik araştırmalarda (Sözer vd., 2002; Görmüş vd., 2013; Hayırsever, 2014; Tosun ve Başgöze, 2015) öğrenci işleri hizmetleri 
en çok şikâyet toplayan üniversite birimi olarak öne çıkmakta ve öğrenci belgeleri, diplomalar ve notlar önemli şikayet nedenlerini oluşturmaktadır.

$\mathrm{Bu}$ çalışmada Öğrenci İşleri Daire Başkanlığı bünyesinde sunulan öğrenci hizmetlerinin tüm boyutlarına (güvenilirlik, heveslilik, fiziksel özellikler, empati, güven) yönelik algılanan ve beklenen SERVQUAL skorları incelendiğinde en fazla fark empati $(-0,65)$ ve en düşük fark ise fiziksel özellikler $(-0,36)$ boyutunda gerçekleşmiştir. Diğer sıralamalar ise güvenilirlik $(-0,53)$, heveslilik $(-0,46)$ ve güven $(-0,43)$ şeklinde tespit edilmiştir. Tüm boyutların SERVQUAL skoru ortalaması $-0,49$ olarak ortaya çıkmıştır. Bu sonuçlar kapsamında Karabük Üniversitesi özelinde Öğrenci İşleri Daire Başkanlığ1 biriminde hizmet sunmakta olan personelin kayıtları titiz tutma başta olmak üzere nezaket ve güvenilirlik konusunda daha çok çaba harcaması gerektiği söylenebilir. Ayrıca bu hizmet birimi küçük düzenlemelerle araç-gereç yönünden yeterli hale getirilebilir. Bununla birlikte Karabük Üniversitesi Öğrenci İşleri Daire Başkanlığ1 tarafından verilmekte olan hizmetlerinin kalitesinin artırılmasına katkı sağlayabilecek öneriler şu şekilde sıralanabilir:

-Öğrencilere yönelik hizmetler tek tek analiz edilerek her hizmet için standartlar belirlenebilir ve mevcut personelden bu standartlar çerçevesinde hizmet sunması istenilebilir.

-Öğrenci istek ve beklentileri hususunda birim personeli gerekli ve sürekli eğitimlerle desteklenebilir.

-Öğrenci işleri biriminde görev alacak personelin seçiminde belirli kriterler (fiziki görünüm, diksiyon, iletişim vb.) oluşturulabilir.

-Öğrenci biriminde sunulan hizmetlerde yeni araçlar kullanılabilir ve konforlu ortamlar (öğrencilere oturma alanları, çay/kahve ikramları vb) oluşturulabilir.

-Öğrenci işleri hizmetlerine yönelik belirli periyotlarda düzenli olarak kalite ölçüm araştırmaları yapılabilir.

-Öğrenci biriminde yoğun iş yükü altında hizmet sunmakta olan personel için motivasyon yükseltme çalışmaları (prim, ödül, yemekler, hafta sonu etkinlikleri vb.) yapilabilir.

-Yurtiçi ve yurtdışı üniversitelerin öğrenci işleri birimleri incelenerek, iyi örnek uygulamalar Karabük Üniversitesi bünyesine taşınabilir.

-Öğrenci işleri hizmetlerine yönelik belirli periyotlarda geri bildirim çalışmaları yapılabilir. Bu çalışma sonuçları tüm öğrencilere paylaşılabilir. 


\section{KAYNAKÇA}

Altan, I. ve Atan, M. (2004). Bankacılık Sektöründe Hizmet Kalitesinin SERVQUAL Analizi ile Ölçümü. Gazi Üniversitesi İ. İ. B. F. Dergisi, 6 (1), 17-32.

Asogwa, B., Asadu, B. U., Ezema, J. U., Ugwu, C. I. \& Ugwuanyi, F. C. (2014). Use of SERVQUAL in the Evaluation of Service Quality of Academic Libraries in Developing Countries.

[Online] $<$ http://digitalcommons.unl.edu/cgi/viewcontent.cgi?article=2947\&context=libphilprac> Erişim: 01.05.2016.

Aslanargun, E. (2007). Modern Eğitim Yönetimi Anlayışına Yönelik Eleştiriler ve Postmodern Eğitim Yönetimi. Kuram ve Uygulamada Eğitim Yönetimi Dergisi, (50), 195-212.

Başaran, (1978). Eğitime Giriş. Ankara: Bilim Matbaası.

Bulgan U. ve Gürdal G. (2005). "Hizmet Kalitesi Ölçülebilir mi?”, [Online] <http://kaynak.unak.org.tr/bildiri/unak05/u05-22.pdf> Erişim Tarihi: 24 Nisan 2016

Cardona, M. M. \& Bravo, J. J. (2012). Service quality perceptions in higher education institutions: The case of a Colombian University. Estudios Gerenciales, (28), 23-29.

Cevher, E. (2015). Yükseköğretimde Hizmet Kalitesi ve Kalite Algısının Belirlenmesine Yönelik Bir Araştırma. Uluslararası Sosyal Araştırmalar Dergisi, 8(39), 804-814.

Çavdar, E. (2009). Yüksek Öğretimde Hizmet Kalitesi Unsurları ve Bir Uygulama. Niğde Üniversitesi İ̈BF Dergisi, 2 (2), 100-115.

Elmacı, O., Poyraz, K. ve Çalık, M. (1999). Yüksek Öğretimde (Meslek Yüksekokullarında) Kalite Güvence Sisteminin Oluşturulmasına Yönelik Bir Değerlendirme Format Önerisi. Dumlupinar Üniversitesi Sosyal Bilimler Dergisi, (1), 111-137.

Hoca, E. (2007). Bir Vakıf Üniversitesinde Eğitim Yönetimi Alanındaki İdeal Lider Tipi Özelliklerinin Araştırılması. Yayımlanmamış Yüksek Lisans Tezi, Yeditepe Üniversitesi Sosyal Bilimler Enstitüsü, İstanbul.

http://www.tuik.gov.tr/basinOdasi/haberler/2015_18_20150407.pdf [Online] Erişim Tarihi: 16 Nisan 2016.

Görmüş, A. Ş., Aydın, S. ve Aydın, M. (2013). Yükseköğretim Kurumlarında Öğrenci Şikayetlerinin ve Şikâyet Yönetiminin Değerlendirilmesi. Uşak Üniversitesi Sosyal Bilimler Dergisi, 6(3), 167-190.

Gürbüz, E. ve Ergülen A. (2008). Yükseköğretim Kurumlarında Hizmet Kalitesi Ölçü ve Modelleri. Ankara: Detay Yayıncilık.

Hayırsever, Y. (2014). İç Kontrolde Öğrenci İşleri ve Paydaş Memnuniyeti İçin Karar Destek Sistemi. Yayımlanmamış Yüksek Lisans Tezi, Karabük Üniversitesi Fen Bilimleri Enstitüsü, Karabük.

Karahan, M. (2013). Yükseköğretim Kurumları Kalite Yeterliliklerinin Öğrenci Memnuniyeti ve Sürdürülebilirlik Açısından İncelenmesi: İnönü Üniversitesi Malatya MYO Uygulaması. Dicle Üniversitesi İktisadi ve İdari Bilimler Fakültesi Dergisi, 2 (3), 1-9.

Odabaşı, Y. ve Barış, G. (2002). Tüketici Davranışıı, İstanbul: MediaCat, 
Okumuş, A. ve Duygun, A. (2008). Eğitim Hizmetlerinin Pazarlanmasında Hizmet Kalitesinin Ölçümü ve Algılanan Hizmet Kalitesi ile Öğrenci Memnuniyeti Arasındaki İlişki, Anadolu Üniversitesi Sosyal Bilimler Dergisi, 8(2), 17-38.

Özgül, E. ve Devebakan, N. (2005). Üniversitelerde SERVQUAL Tekniği İle Algılanan Hizmet Kalitesinin Ölçülmesine Yönelik Karışlaştırmalı Bir Araştırma. Yönetim Bilimleri Dergisi, 3 (2), 93-116.

Petruzzellis, L., D'Uggento, A. M. \& Romanazzi, S. (2006). Student satisfaction and quality of service in Italian universities. Managing Service Quality, 16 (4), 349-364.

Somaratna, S. D. \& Peiris, C. N. (2011). Service Quality in University of Colombo Libraries: An Assessment. Annals of Library and Information Studies, (58), 170-183.

Sözer, A. N., Tütüncü, Ö., Doğan, Ö. İ. vd. (2002). Dokuz Eylül Üniversitesi Sosyal Bilimler Enstitüsü'nde Lisansüstü Eğitim Kalitesinin Arttırılmasına Yönelik Bir Alan Araştırması. Dokuz Eylül Üniversitesi Sosyal Bilimler Enstitüsü Dergisi, 4 (2), 41-65.

Taymaz, A. H. (1995). Okul Yönetimi. Ankara: Saypa Yayın Dağıtım ve Kitapevi.

Tayyar, N. ve Dilşeker, F. (2012). Devlet ve Vakıf Üniversitelerinde Hizmet Kalitesi ve İmajın Öğrenci Memnuniyetine Etkisi. Muğla Üniversitesi Sosyal Bilimler Enstitüsü Dergisi, 28, 184-203.

Tosun, M. U. ve Başgöze, P. (2015). The Service Quality Perception in Student Affairs: A Single Institutional Experience. Hacettepe Üniversitesi Ĕ̆itim Fakültesi Dergisi, 30 (3), 131-146.

Üner, M. (1994). Hizmet Pazarlamasında Pazarlama Karması Elemanları Değişiklik Gösterir mi? Pazarlama Dünyası Dergisi, 8 (34), 2-11.

Yılmaz V., Filiz Z. ve Yaprak, B. (2007). SERVQUAL Yöntemiyle Yükseköğretimde Hizmet Kalitesinin Ölçülmesi. Anadolu Üniversitesi Sosyal Bilimler Dergisi, 7 (1), 299-316. 